Weir, David T.H. ORCID:

https://orcid.org/0000-0002-6750-6722, Sultan, Nabil and Bunt, Sylvia van de (2019) Doing Business in the Arab World: Unlocking the Potential of Wasta. In: Globalization and Development.

Springer, pp. 323-341

Downloaded from: http://ray.yorksj.ac.uk/id/eprint/3878/

The version presented here may differ from the published version or version of record. If you intend to cite from the work you are advised to consult the publisher's version: https://link.springer.com/chapter/10.1007\%2F978-3-030-11766-5_12

Research at York St John (RaY) is an institutional repository. It supports the principles of open access by making the research outputs of the University available in digital form. Copyright of the items stored in RaY reside with the authors and/or other copyright owners. Users may access full text items free of charge, and may download a copy for private study or non-commercial research. For further reuse terms, see licence terms governing individual outputs. Institutional Repository Policy Statement

\title{
RaY
}

Research at the University of York St John

For more information please contact RaY at ray@yorks.ac.uk 


\section{Doing Business in the Arab World: Unlocking the Potential of Wasta}

\section{Prof. David Weir}

Professor of Intercultural Management, York Business School, York St. John University, UK Tel: +447833366773

Email: d.weir@yorksj.ac.uk

\section{Prof. Nabil Sultan}

Dean of the College of Business Administration, A'Sharqiyah University, Oman

Tel: +96892700520

Email: nabil.sultan@asu.edu.om

\section{Dr. Sylvia Van De Bunt}

Co-Director of the Servant Leadership Centre for Research and Education (SERVUS), Vrije Universiteit Amsterdam, The Netherlands

$$
\text { Tel: }+31205986105
$$

Email: s.vande.bunt@vu.nl

Chapter contribution to the Springer book "Globalization in Developing Economies" edited by Nezameddin Faghih

This manuscript has not been submitted or published elsewhere. 


\begin{abstract}
Wasta is a way of social networking, of using connections, overcoming personal and/or family dilemmas or conflicts. Wasta may provide solutions to dilemmas in societies that had or still have limited opportunities for progress and economic development. This phenomenon has important implications for business networking, especially for indirect and global networking in uncertain business situations. Despite increasing interest in understanding the importance of business networking in general, the networking systems already prevalent in many cultures whether known as Wasta, in the Arab world Guanxi in China or Blat in Russia, have been relatively ignored. Wasta has intrigued many people and raised questions of its origin, reasons and consequences. In relation to many Arab countries the word Wasta evokes negative sentiments even amongst its citizens Media outlets and government announcements often denounce Wasta. However, Wasta continues to be widely practiced in developing economies in the Arab world and is in many situations accepted as a normal feature of these societies. There are many dimensions to this phenomenon: historical, cultural, social, political and global and it is impossible in a short chapter to do justice to all of these aspects. We accept that the precise operation of Wasta differs from one country and social milieu to another. There are over 20 countries conventionally accepted as being part of the "Arab world". So, in this chapter we only deal with the general features of Wasta found in most parts of that region and explores a new approach for understanding the opportunities of Wasta to continue to exist as a means of conducting business in the Arab World alongside other social networking practices in the era of globalization. We base the analysis on the need to understand the operation of social and organisational networks. No special position is taken in this chapter on the ethical and moral issues that sometimes dominate discussion of these topics. But we point out that regardless of any ethical concerns, there is no doubt that these systems exist and are a powerful reality. However, we argue that in considering such issues as entrepreneurship and business development the existence of Wasta relationships should not be overlooked or undervalued.
\end{abstract}

Keywords: Wasta; globalization; Modernisation; Arab; Western, social networking, interpersonal trust, entrepreneurship

\title{
INTRODUCTION
}

Globalization has greatly impacted developing economies in the Arab World as elsewhere. Local businesses emerged through internationalization, causing cross-cultural challenges for Arab social networks. Yet along with this, there continues to be a lack of knowledge about 
Arab social networks. Scholars, even those willing to go beyond the classical western-based paradigms in order to intensify awareness of other cultures, have so far presented few radically new thoughts on social networks in the Arab World. Here we will focus on 'Wasta', the social network system in the Arab World. Although Wasta is known as a characteristic feature of Arab World business practices it is too often portrayed in an exclusively negative aspect, implicated in the stigmas of corruption and cronyism (Doughan 207, Sapsford, Tsourapas, Abbott \& Teti 2017, Feghali 2014, Anderson 2016). But these taints represent only part of a more complex and nuanced picture.

This negativism about Wasta is curious because organisational networking as a wider phenomenon is usually portrayed in organisation analysis literature as a desirable organisational activity contributing to increased network knowledge, improved customer and client potential and greater access to entrepreneurial opportunity (Thornton, Henneburg and Naude, 2013). The traits above all of ability to establish networks and ability to optimise existing networks, some of which may be latent and constitute potential rather than actual bases for earning, are highly prized in discussions of business networks in global business (Chaston and Mangles, 2000). The question as to whether Wasta represents a scourge or a valuable social practice is discussed by some authors and explicitly by Weir, Sultan and Van de Bunt (2015). There are several country-specific studies reporting on Wasta. Examples include those by Cunningham and Sarayah (1994) on Jordan, Mann (2014) on Sudan, Brandstaetter, Bamber and Weir (2016) on Jordan, Al-Hussain and Al-Marzoog (2016) on Saudi Arabia, Karalok (2016) on Bahrain, and Azra (2016) on Indonesia.

It is bold to speak of the "Arab World" in general at all in the context of globalization. This region exhibits a rich internal diversity: however some social and cultural phenomena such as Wasta are widespread in these countries and cultures and form an integrating and recognizable matrix of behaviours and beliefs. Similarly to the cultural situation in Europe, we find in the Arab World, on a local and national level, various diverse attitudes and behaviour. On the national political level of Arab countries, systems of government and administration may differ significantly. Nevertheless, on a cultural level various similar features with more or less impact can be observed (Chennoufi and Weir, 2000). Hickson and Pugh (1995) describe similarities across the Arab World in features such as oil, Islam, Bedouin historical roots, the joint history of foreign governors, and colonialism (Hickson and Pugh, 1995). The economic developments in the Arab World have important implications for the Western world. Furthermore, on a global scale, adherents of Islam represent $24 \%$ of the world's population (Weir, 2003b, and Lipka \& Hacket, 2017) and 20\% of these are in the MENA countries (Weir, 
2003b). By the end of the $21^{\text {st }}$ century it is estimated that Islam will become the world's largest religion, overtaking Christianity by 2050 (Pew, 2015).

\section{A NEW APPROACH FOR UNDERSTANDING WASTA}

We argue in this chapter that Wasta needs to be explored from a different perspective: one that looks at the entrepreneurial side of this interesting social and behavioural phenomenon. Wasta is continually evolving in a changing evolutionary process that has created new challenges and opportunities for the people who are affected by it (Weir, Sultan, and Van de Bunt, 2015).

The practice of Wasta could be facing challenges in this era of globalisation that is evidently heavily and dominantly influenced by Western theories and practices of management and business. However, rather than dismissing this Wasta phenomenon as an alien concept, we argue that understanding how Wasta works is essential in an era of globalization to all who plan to do business with the Arab World. This understanding could provide a potential for blending Eastern and Western business theories and practices. Subsequently, new crosscultural insights can become applicable in a networked global society.

It is accepted that no firm exists in isolation from the network of relationships in which it is embedded; the interconnections and aggregations of business networks are central to the operation of markets at regional, national and global levels (Anderson, Håkansson, \& Johanson, 1994). These networks comprise both direct and indirect connections. Firms that can capitalise on the opportunities available within both the direct and more importantly the indirect and remote linkages available in a network can operate more efficiently and reap competitive advantage and better financial rewards (Ford, D., Gadde, L. -E., Håkansson, H., \& Snehota, I. 2003, 2006). While being embedded in a complex network with uncertain and unpredictable forces in play may act as a restraint or barrier on individualistic strategies of profit maximisation (Burt, 2003), it can also create unplanned and un-forecast opportunities provided that there exists some process of modification of negative forces and protection against the potential impact of unknown influences within the network such as is available through the mediating processes and the linkage between the individual and organisational level offered by the existence of Wasta in which weak ties exist and remain latent until activated (Granovetter, 1973, 1985, 2005).

Ouchi (1980), Scott (1991a), Williamson (1979), Dwyer (et. al., 1987) and various other authors analysed the macro-development of Western capitalist economies and their social networks. These authors were primarily interested in the analysis of transaction costs, and of 
the explication of dimensions in the interaction and social exchange of organisations. Social network analysis includes the description of limiting and empowering levels of individual relationships and focusses on the empirical analysis of social events in a system of space and time (Garbett, 1970).

According to Mitchell (1969) social networks represent "a specific set of linkages along a defined set of persons with the additional property that the characteristics of these linkages as a whole may be used to interpret the social behaviour of the persons involved". Mitchell also examined how the social structure and human relations not only affect individual persons. Besides the individual level, Mitchell also investigated how the social structure and human relations affect the society at large, e.g. its impact on societal cohesiveness. Mitchell building on the work of Barnes (1954) argued that both the 'structure' as well as the 'content' of social relations need equal attention as social networks endure in both informal and institutional structures, so formal structures and informal relations both contribute to lived culture (Mitchell 1974). Importantly Mitchell (1974) points out that network positioning is different from social role as "Several roles may thus coexist in one network link so that operationally the emphasis must be placed on the institutional settings in which people extend their network link. In Mitchell's research 'partial networks' (Mitchell, 1969, 283) were identified. According to Scott (1991b) the 'partial networks' can be seen in particular on an individual level. On the other hand, global networks relate in particular to social activities. Social activities may include family obligations, or relations with friends or colleagues.

Given the work of Mitchell $(1976,1969)$ and Scott (1991b), the features 'multiplex', 'density', 'reachability', 'reciprocity' and 'durability' became subject of social network analysis and there have been attempts to formalise these explanatory concepts and make them amenable to mathematical analysis (Barnes,1969). Extension of network methods to topics like Accounting and Auditing are proposed by Kacanski and Lusher (2017). According to Scott (1991b) in multiplex networks two actors are connected through more than one link. Density is defined as the level of possible links between the individuals involved. Reachability means how easy it is for individuals to exchange resources or communicate within the network (Mitchell, 1976). To analyse the quality of the interpersonal networks, three concepts can be used. First, the concept of reciprocity (namely the extent to which an interpersonal network is reciprocated), secondly the intensity (weight of duties) and finally the duration of the relations, namely whether lasting or temporary (Mitchell, 1969). Granovetter $(1973,1985)$ reinforces the value of strong network ties but also the importance and benefit of sporadic and short contacts, the so called 'weaker ties'. Uzzi (1996) points out the value of "embeddedness" in a network as a support for increased organisational effectiveness. 
A useful typology of organisational networks is provided by Thornton, Henneberg and Naude (2013) who break down the notion of network management into the dimensions of network competence and networking capability. They follow Ritter's definition of Network Competence as "the degree of network management task execution and the degree of network management qualification possessed by the people handling a company's relationships" (Ritter, 1999). Networking capability means the activities, processes, systems and routines embedded in practice and enforced through regular use in the process of doing business (Thornton, Henneberg and Naude, 2013; Mort and Weerawardena, 2006, Mitrega, Forkmann, Ramos, \& Henneberg, 2012). The emphasis of these contributions is primarily on the strategic and purposeful motivations of enterprises in pursuing identifiable objectives and planned developments of their corporate goals. But nonetheless Thornton, Henneberg and Naude suggest that "the strong and weak tie argument has shed some light on firm performance from a structural network perspective, but the challenge for individual firms remains somewhat unexplored.." (Thornton, Henneberg and Naude, 2013; p 1157). Building on this new approach described above, we argue that Wasta also provides an effective support for investigating, observing and interrogating the unknown aspects of organisational life. Wasta thus has more potential than the explicitly planned tactics of organisations in utilising their existing networks. Wasta is an important aid to organisations in dealing with uncertainty.

\section{WASTA BETWEEN TRIBALISM AND ISLAM}

What is the difference between doing business in the Arab versus the Western World? We argue that the cultures and processes of personal and organisational life intersect rather differently from those that exist in Western business contexts: they are less formalised and organised into precise and predictable legal and formal structures. Basically, Arab business starts from building social relations first between the stakeholders. Building the personal relationship is very time-consuming. A fundamental set of expectations around standing, including but not restricted to financial status, trustworthiness and capability require to be met, Meetings of a decisive nature in which desired outcomes are pre-determined and announced in such phrase as "the purpose of this meeting is to..." or "this should not be a long meeting..." may not be as common or as highly prized as in the West. The Wasta system may make a process of negotiation longer but makes the chances of reaching consensus decisions acceptable to a wide range of interests more likely. It is quite possible and may be indeed unnerving to the Western manager to emerge from a meeting in the Arab world uncertain as to what has been decided and agreed. Conversely it is possible to find that one is apparently in the middle of some activity that has not been formally authorised and announced but has apparently already started. Only after some time spent in becoming available in a market 
situation and announcing with various degrees of subtlety that one is available, a first official business meeting will be organized, where the core of the proposed business will be addressed. The informal process takes time and verbal agreements are the core and root of agreement once the interpersonal relationship is established. The word of an individual business stakeholder is binding and generally not fulfilling a personal verbal contract will terminate your business opportunity (Weir, 1998). Such Arab business practices are enforced fundamentally in the universality of the practice of Islam. Furthermore it is assumed that Muslims worldwide execute Islam in good faith and refer to its implicit understandings as a matrix of universal obligations. This is an enforcing factor that does not usually need further explanation.

Thus a major factor underpinning Arab business is the operational networking context of Muslim societies, where business activities originate from these networks. These networks are the context of Wasta and its interpersonal ties. The strength or weakness of these social connections has implications for the level of access to power, influence and information sharing in business networks. In this sense, the strength or weakness of the Wasta tie is intrinsic to valuable social processes, getting access to knowledge, and business opportunities, or not. The improvement of knowledge-sharing capabilities based on increasing trust between potential business partners contributing to the breaking down of the barriers to knowledgesharing and knowledge transfer noted by Riege (2005) is one of the most likely outcomes of active Wasta processes. Compare the concept of Wasta with a similar phenomenon Guanxi in China. Guanxi has on the one hand helpful implications of networking and, on the other hand, undesirable implications of corruption. Likewise, these implications may occur in Arab Wasta networks. Comparisons between Wasta and guanxi can be illuminating and more research is required on comparative frameworks (Hutchings and Weir, 2005, Li, Du, and Van de Bunt. 2015, Weir, Sultan, and Van de Bunt, 2015).

On the one hand, Wasta is part of wider Arab culture and Arab decision-making across the globe. On the other hand, only very few business authors write about Wasta. And even Arabs themselves do not always openly discuss Wasta matters (Sawalha, 2002). What causes this hesitation to write and speak openly about Wasta? According to Weir, Sultan and Metcalfe (2011) and Sultan, Metcalfe and Weir (2011) this is caused amongst others by the attitude of Arab governments in their efforts to play a role in the increasingly globalized world. These Arab governments invite global investors and aim to develop a modern $21^{\text {st }}$ century state. In the official governmental media Wasta is often framed as something negative. At the same time, civil servants of these governments may practice Wasta to buy favours. 
It is difficult if not impossible even to abstract what may be termed as Wasta activities in business and commercial affairs from the general structures and processes of Arab society. The Arab society is highly collectivist but also strongly personalized. Or, as Zakaria, Stanton, and Sarkar-Barney (2003) state "Arabic cultures tend to know more about each other than Westerners". Thus, socializing activities directed to strengthen existing social bonds and maintain interpersonal connections are essential features of Arab business, family and sociopolitical life.

One interesting and illustrative story in this regard is worth mentioning. The story is about the daughter (Rabe'a) of Sheikh Abdulla bin Hussein Al-Ahmar, the most powerful tribal Sheikh in Yemen. She was found dead in Jordan in 2003. Her Jordanian husband, Mumdooh AlShalaan, the son of a powerful Jordanian tribal Sheikh, was arrested by the Jordanian authorities and accused of her murder. The Shalaan family sent in 2004 a high level delegation (jaha), comprising up to 40 people, to Sheikh Al-Ahmar that also involved King Abdulla of Jordan and President Ali Abdulla Saleh of Yemen. Sheikh Al-Ahmar finally forgave the husband for the murder of his daughter (Asharq Alawsat, 2004). What can we learn from the above story? Intercessory Wasta involves a leading figure mediating as representative of a customer (in this case the Shalaan family) to gain a benefit for the customer. Benefits may include advantages such as getting a good job, crucial information of a governmental institution, tax waiver, or access to a top university. In situations of strong competition for the same benefits, only candidates with the soundest Wasta network will win (Cunningham and Sarayrah, 1994). Critical reviewers consider arbitrary Wasta as unlawful. However, those critical reviewers remain to practice and deliver Wasta advantages (Cunningham and Sarayrah, 1994).

Islam claims to be a religion of universal obligation rooted in practice that can be applied across the globe (Weir, 2003a). The Islamic pattern of behaviours and principles, affecting the whole of people's life, also has implications for the world of business (Weir, 2003b). The five pillars of Islam imply practical obligations rather than abstract statements of belief, namely stating that there is one God and that Mohammed is his prophet, praying regularly, paying alms to people in need, observing Ramadan and making the Hajj, the pilgrimage to Mecca (Weir, 2012). These precepts affect the world of business and organisational life equally as all other dimensions of life in both complex and simple societies (Weir, 2008).

Islam emerged as a universal religion that was not meant for Arabs only. The pre-Islamic era in the Arabian Peninsula is regarded by Islam as a period of ignorance (Jahiliya). This period was famous for its tribal warfare and conflicts. Islam insisted that it becomes the focal point 
for people, not their tribe or indeed family. By declaring Muslims as brothers, Islam has sought to effectively abolish tribalism among the faithful. Wasta has its roots in earlier tribalism and is in a way inconsistent with the Islamic style of wealth distribution. In the Quran (Quran, Al-Qasas: chapter 28, verse 26), Muslims are instructed to hire people on merit as depicted in the story of Moses. Two women (as narrated in this surat) were unable to water their flocks because the water was being monopolised by a crowd of shepherds. But when Moses helped them water their flocks despite the presence of the shepherds, one of the women went to her father and said to him "O my father, hire him. Indeed, the best one you can hire is the strong and the trustworthy." A number of sayings on this point are attributed to Prophet Mohamed. He is attributed to have said "He who is in a leadership position and appoints knowingly a person who is not qualified to manage, then he violates the command of God and His messenger" and "When a person assumes an authority over people and promotes one of them because of personal preferences, God will curse him for ever" (Ibid). Umar ibn AlKhattab, the famous and strict third Calif (or Commander of the Believers) after Mohamed was very careful, and meritorious, in selecting and appointing his civil servants. They were required to have good characteristics such as piety, ability and trustworthiness. Once selected, they would be appointed on a probationary period of two or three months to test their suitability before being permanently confirmed in their positions. Furthermore, he ensured that his state officials were being adequately paid to prevent dishonest practice, e.g., bribery (Sultan, 2013).

But the old habits of tribalism resurfaced after the death of Umar. The era of the Calif Muawiya Ibn Abi Sufian (the first Umayyad ruler), in particular, heralded a period where tribal affiliation, familial and personal loyalty took precedence over merit and religion. This situation lasted for centuries. Some modern manifestations of it exist to this day.

\section{WASTA AND GLOBALISATION}

Fuller and Lesser (1996) argue that historical cultural values are confronted with a multitude of other cultural values introduced from abroad. Wasta will remain a feature of Arab societies as long as its disadvantages remain an insignificant political issue. Al Suwaidi (2008) is one of many commentators to point out that Wasta is seen to have a neutral positioning in classical Islamic values as applied to business. The crucial distinction between "good Wasta" and "bad Wasta" first and for all relates to the intentions of the person using Wasta processes, rather than to any intrinsic quality of Wasta as such. However, this rationalisation ignores the cultural fabric of Arab society where kinship and family ties often impose obligations on 
people to engage in Wasta. Not fulfilling those obligations risks damaging social and family relations which are important in societies living in volatile political environments characterised by insecurity, poverty and unpredictability. Moreover, this rationalisation ignores the political establishments that govern Arab societies, which rely on a system of patronage for their survival. The "call for significant social change" came with the Arab spring of 2011. But that call failed to shake or change the status quo. Another "call for significant social change" came from Saudi Arabia in 2017 with the ascent to power in 2015 of Prince Salman Bin Abdul Aziz (as King) and later his young son Prince Mohamed Bin Salman (MBS) as Crown Prince who spearheaded that call. In a country notorious for corruption and Wasta, MBS unleashed a campaign to fight these two problems in Saudi society in a very unprecedented way. He arrested and imprisoned many rich Saudi businessmen and royal family members on allegations of corruption. MBS exacted millions and billions from them for their release, and vowed to clean Saudi society of this "scourge". But these are early days to pass judgement. Only time will tell if this campaign has resulted in a significant social change in Saudi Arabia. This is assuming MBS remains in power - and later becomes King to see the outcome of his actions. However, the Saudi political system may struggle to overcome problems of insecurity, poverty and unpredictability. As a consequence, in the immediate to mid-term Wasta will continue to remain a "normal" feature of Saudi society.

Will globalization of higher education weaken Wasta? This question is often being asked in the Arab world. The recent proliferation of satellite campuses of respected Western universities (Arnove, Torres, Franz, 2012) in different Arab countries is immense. These universities offer undergraduate and postgraduate degrees in business and other disciplines. It is too simple to assume that 'Western/modern' can be differentiated from 'Arab/traditional' in these universities (Dadfar, 1993; Weir, 2003b, Weir, Sultan, and Van de Bunt, 2015). It is too easy to suppose that Arab business people have greater access to Western business theories, and consciously decide to follow Western models therefore Wasta predictably weakens. Mann (2014, p.563) investigated the Islamist movement in Sudan's higher education. In her survey of 400 professionals, Wasta appeared not to weaken but to be growing more influential and stronger. In Sudanese higher education Wasta is a system of loyalty through personal networks. Wasta is a powerful network to get access to the best school or job. In Yemen, in one of his customary outbursts, Ali Abdulla Saleh (Yemen's ex-President) once (on television) accused Western educated Yemenis who return to their country of being more corrupted than before they left Yemen. Saleh, who was forced to leave office in 2011 following mass street uprisings (and later assassinated in December 2017), is alleged to have amassed a fortune of US\$ 60 billion through misuse of his position during his 33 years rule. 
In this respect Hampden-Turner and Trompenaars (2015) offer a stimulating overview of the variety and diversity of business cultures. This overview implies how fruitless the facile assumption is that all roads inevitably lead to the Anglo-American MBA culture. According to Stanton (1999) Arab business people are not resistant to change. However, these globalization issues need to be discussed in the Arab cultural context (Ayubi 1986; El-Tayab 1986). According to Hooker (2008) business schools worldwide are influenced by Western paradigms of rule-based cultures. Hooker (2008) contrasts rule-based cultures (such as those in the West) with relationship-based cultures (such as those in the East) where personal relations assume importance in transactional activities. Despite this generalised dichotomy, local business attitudes and cultures vary across the globe. The dominant paradigm in management education originated from Western management thinking. However, the Arab business paradigm is inseparably associated with the Arab social organisation and its core values. According to Weir (1998): "These features, far from being deviant or undeveloped versions of Western business models, may provide the basis for a style of management organisation well suited to the growing requirements of a networked global society". Some may deny or negate desirable meanings of Wasta. Nevertheless, we argue that the Arab business style has great relevance for cross-cultural theory building in higher education, to understand and apply in the era of globalization.

\section{MANAGERIAL AND BUSINESS IMPLICATIONS}

Rice (2004) and Hutchings and Murray (2002) highlight managerial implications for doing business with Chinese and Arab counterparts. Global managers should do research and prepare beforehand. Buckley and Casson (1988) argue the global dimension is even more important than the intercultural dimension, while doing business in China or the Arab World. The cultural gap is undeniably big between Arab and Western business people. The bigger the gap, the bigger the probability for misinterpreting. Cross-cultural misunderstanding may severely hinder building trustful social relations (Park and Ungson, 1997; see also Hofstede, 1980; Brouthers, 2002; Hennart and Larimo 1998, Trompenaars and Hampden-Turner, 1997, Trompenaars and Coebergh, 2014).

\section{Hadhrami Case}

Using Wasta to help people from their own tribal clans start their own business has been a feature that, for example, characterised Hadhrami lives in their diasporic history. Hadhramis are Yemenis who originate from the Eastern region of Yemen known as Hadhramaut. Many Hadhramis migrated to South East Asia, East Africa and the Gulf region centuries ago and became successful business people. A great deal of their success is attributed to helping their 
own Hadhrami clansmen through Wasta. They would often employ Hadhramis to work for them and help others to set up their businesses by lending them money or goods. Some of these entrepreneurial activities would, in most cases, go through Wasta e.g. one person who introduces another person. Trust is central to how Hadhramis do business. Helping their own people ensures loyalty and is an insurance against default. Hadhrami businessmen would normally not resort to courts to settle their disputes but would appoint someone from their own midst (often a respected figure) to take this role (Sultan and Weir, 2010).

Barnett, Yandle and Naufal (2013) acknowledge economists have neglected Wasta. This lack of attention is rather common, despite its significant meaning for the globalizing business world. There are indeed serious issues about the analysis of resource allocation in these economies, some of them specific to this region and its socio-political mix. For these serious issues a more refined discussion of Wasta's managerial and business applications could be relevant (see Kar, Naziuoglu and Azir 2011, and Loewe, Blume, Schonleber, Seibert, Speer, and Voss, 2007). Wasta undoubtedly needs to be defined in terms that render it susceptible to economic analysis. Such interpretation could enable linkages to be made with some long standing economic issues, especially in this era of globalization. This is because, in global industrial economies there is still a need for diversity of economic practices and opportunities for scale advantages to be procured. Perhaps it has been too often simply assumed that the existence of social networks represents merely a distortion of "free trade perfect competition" assumed in Western markets. As Al-Meles (2007) argued in his Kuwait study, Wasta represents a grounded and fundamental expectation of market behaviour rather than a source of stigma (Hamdy 2008). Wasta is a way of life and a way of doing business. At the least, there is scope for empirical accounts of how and where efficiencies exist.

Furthermore, Wasta may also be seen as a positive influence in the creation of conditions of increased access to markets and permitting subaltern groups to enter markets on improved terms. Bailey (2012) suggests such easier market access may be the case for young Emirati females. This proposition is supported by other studies that subaltern Wasta may tend to mitigate the restraints of existing gender constraints, and at the same time attempting to develop new business in a non-business friendly environment (Mulnix, Beede, and LópezMulnix 2014; Mathew and Kavitha, 2010). Sadi (2017) argues that positive Wasta can serve a noble and honourable purpose to help marginalized people and reach equal opportunities. It is generally conceded that the emergence of a globalised world economy brings both benefits and threats. Thrift (1993) has argued that a cautious mix of optimism and regulation provides a strong basis for the success of the Netherlands in the globalised world. Thrift's suggestion highlights the important role of widespread regulation in the Arab world: but this is not so apparent to the Western manager because such regulation tends to 
be based not on explicit legal structures and statutes but on internalised paradigms of behaviour and fundamental shared assumptions about behaviour and practice. Globalisation of business has created increased uncertainty and this exposes managers to increased challenges. But, arguably Arab societies are better able to deal with this kind of uncertainty because it is the essence of competence to understand that all life is subject to uncertainty. What is planned for by organisations and individuals alike may be interfered by events and circumstances. Fundamentally no entity other than God knows all can be credited with perfect knowledge. Wasta (especially Mediatory Wasta) is essentially a social mechanism for dealing with the unexpected. These cultural styles are of course not unknown in other parts of the world. In the North of England Yorkshire folk are credited with a cautious not to say pessimistic outlook in business and personal matters. Thus maxims like "always expect the worst and it may turn out worse than you expected" are taken as reasonable guides to business and social life and will historically have been equally associated with the inculcation of resilient behaviours among Bedouin desert-dwellers. These are reasonable guides to action, and reasonable grounds for belief and action.

Globalisation may have increased risk for individuals and organisations. Solutions to solve these risks may not lie merely in measures to bound the area of uncertainty and act according to what one does know compared to previous experience. On the contrary, dealing with these risks may instead lie in greater mature acceptance of what Rumsfeld (NATO, 2002) called the "unknown unknowns". Mature acceptance implies that these risks will always be present in complex situations. Trusted friends will always be advantageous in complex situations if things do not turn out as expected.

We propose that if international business people, or in other words global managers, want to be successful in the Arab World they must come to terms with Wasta practices and learn to comprehend this phenomenon. They need to become familiar with the Arab insider relationships accompanied with features such as trust, family and favours. These doors may seem to have cultural locks, but the right respectful keys in cross-cultural communication may open them. Fundamental to establish a position in a Wasta framework is to learn with empathy. This means you need to take time to create trust and to comprehend or accept that in these worlds there are no fixed divisions between what is a "business" and what is a "family" or a "social" relationship. At the same time the cross-cultural communication provides a mirror to global managers. They will become more aware on their own cultural context and reflect on the roots of their own social network versus the Arab context. Cross-cultural business communication is about building trust and obtaining understanding and commitment 
to local business interests. There needs to be much active listening (Schein, 2013) and much acceptance in order for business relationships to grow in potential; value, reciprocity and accessibility. Cross-cultural training will improve the capabilities of global managers and assist them in establishing new skills. Training in these new skills will help creating and maintaining relationships and appreciating opportunities to engage in local economies, such as in the Arab World (Aljbour, 2011).

Evolving styles do not necessarily need to be bifocal and represented only as paradigmatically as "either/or". Increasingly they will segue into hybrid and emergent forms and able to be played as "both/and". As Gold and Naufal (2012) stipulate, Wasta signifies an "immutable social phenomenon". According to these authors, Wasta will inevitably be incorporated into new ways of operating on both sides of the cultural equations. Pressures towards Best Practice and Competitive public sector excellence will reinforce these tendencies (Alsane, 1994): nonetheless the special influence of Wasta practices will not be necessarily diminished.

In the emergence of these hybrid models cross-cultural learning will take place more often. There are fortunately increasing signs that the West can learn as well as provide role models. "Culture" and its defining symbolisations are not imprisoning boxes but facilitative points d'appui, opportunities as well as conceptual prisons. Wasta has central significance for social networking in the Arab World in the era of globalization. At the same time Wasta does not map clearly and unambiguously on to the dark side of a perfect Western liberal free market depiction, but represents a new approach for understanding market and business dynamics.

Therefore there are several implications both for Western and other non-Arab managers entering the Arab world and planning to undertake business there. These Western managers are usually accustomed to Western styles of decision making in which quick response and decisions are based on evidence. Evidence based decisions preferably are expressed quantitatively and financially. Western managers will be surprised to discover that decisions usually take time in the Arab world. In the Arab World it is more important to achieve a viable decision that takes account of the long-term interests of all parties. Western managers have to learn patience because Wasta-based decisions take time to include a wide range of interests. Accustomed to paper-based, Western contractual specifics, in the Arab World it is necessary to accept that work may start before all aspects of a deal are signed off. So long as there exists trust between the parties, a certain amount of flexibility is acceptable in the Wasta system. The diwan style (Weir. 2010) allows for much informality; the diwan space creates an informal discourse, different from a Western pre-planned meeting with advance notification. The expectation within a Wasta network is that a consensus can be attained without fixed and 
binding formal and particularised contracts covering all contingencies (Weir 2010). If trust is lost no amount of contractual rigour can bring it back. Members of a Wasta network may find that experience and seniority, and especially closeness to the ultimate decision-maker, count for more than technical expertise and specific subject-based knowledge. In the end, what is respected as wisdom is more significant than mere professional capability.

These learning points apply to enterprises of all sizes and standing but are perhaps especially important for SMEs to understand. We cite here a story involving two senior British academics from a business school with knowledge and experience in Arab cultural affairs. They once worked as cultural advisors for a British SME that wanted to enter the UAE energy market. The advisors tried to educate the senior management of this company of the importance to establish trust and relations with the relevant UAE people. They advised that the CEO might have to make several trips to the UAE before any business can be established. However, the CEO was not willing to spend travel and hotel money on something that might not guarantee a business transaction. As expected, that company failed to enter the UAE energy market and had to look elsewhere.

\section{CONCLUSION}

Globalisation has brought many new and reinstated some older necessities. One of which is the need to understand how people do things in their own cultures. Not every culture and its adherents see itself as a one-way train rolling inexorably down tracks that can only lead to the Western world or to some pale inauthentic cultural imitation of it. This is particularly important from an increasingly global business networking viewpoint. The Arab World in its diverse forms contains one of those unique cultures. It had a colourful history that was influenced by many factors, which shaped its character. Wasta is one aspect of that culture. In this chapter, we indicated that Wasta has some negative aspects to it. However, we claimed also that it might be useful to look at this phenomenon from a different (and potentially useful) perspective: one that takes notice of its entrepreneurial side In doing so, we suggested that Western businesses should regard it as a type of management and a way of doing business that is different. As such, global managers doing business in the Arab World should learn from it and try to adapt and reconcile their subsidiary business operations to this Arab mode of managing and doing business.

We do not propose that Arab managers are unaware of Western ways of doing business, nor that there are many Western organisations that understand and appreciate the Arab ways of doing business. But we believe that at this point it is the Western organisations that have more to learn and more to gain from the mutual learning process. It remains clear that business 
relationships in Arab emerging economies strongly emphasise the importance of personal relationships and that the intersections between what is regarded as personal and what as organisational occurs in different places and is related to different expectations in the Western and Arab styles.

Put very simply it is accepted in the Arab philosophy that personal integrity is fundamental to interpersonal trust. Personal integrity and trust must be regarded as a fundamental capability and pre-requisite of undertaking any business. The bases of trust are perceived as not bounded by particular organisational contexts but to indicate and validate general, over-arching qualities on which relationships can be founded. This tendency has remained central to Arab business styles in both public and private sector contexts as noted several years ago by Badawy (1980). To develop a personal relationship with actual or potential business partners remains a positive value in the Arab World, perhaps even taking precedence over performance of any single business task. Kabasakal and Bodur (2002) and writers like Rice (2003) are right to emphasise that this is something that Western managers need to be aware of, and to act accordingly. To presume that any delays in reaching agreement are related to Western objective calculated features of the discussion, such as Cost, Price and Delivery may be to seriously miss the point. These Western features involve losing some opportunities to learn more about the nature of the proposed Western-Arab business relationship. It is not all about "business" and "business" is not all about the calculated "bottom line". Interpersonal trust comes first.

This chapter hopefully has contributed to understanding the social network approach of Wasta in the Arab World and in the era of globalization. We shed some light on why Wasta functioned in the Arab World for many centuries and still works notwithstanding the unavoidable trend of globalization. Wasta systems represent social networks in action with the advantage of assisting the rapid informal and formal processing of valuable information and making mediatory powers available to a wider group of organisational players. The existence and importance of networks is currently being rediscovered in the mainstream Western literature as Value-Creating ecologies (Hearn and Pace, 2006) and as CEO strategies. ( Larsen and Ellersgard, 2018) and as essential supports for relationship-based marketing (Leuthesser and Kophli, 1995) : it would be unwise to overlook the obvious facts that these very outcomes may be naturally available advantages of Wasta-based systems.

Future research must further boost awareness among global managers of the pros and cons of operating effectively in socially networked societies like those found in the Arab World. Above all, we suggest that the Wasta frameworks, which exist and have developed more or 
less naturally and organically within these Middle Eastern cultures, are worth the effort of understanding in their own right. Because, they may already possess many of the attributes which have to be learned by newcomers to these highly-networked markets as well as to be sought through specific skills-development in the more formalised and legally-structured societies of the West. 


\section{REFERENCES}

Abderrezak, A. 2007. Colonisation's long-lasting influence on economic growth: Evidence from the MENA region, The Journal of North African Studies, 9(3), 103-112.

Aljbour, R.H. 2011. Wasta and Non-Arab Training, Characteristics, Task, and Culture in Arab Markets, PhD. Dissertation of Lynn University ISBN 9781124568928.

Al-Hussain, F. and Al-Marzooq, A. 2016. Saudi Men and Women Work Participation: The Use of Wasta to Overcome Sociocultural Barriers. In : Ramady, M.A. (editor): The political economy of Wasta: use and abuse of social capital networking: Berlin: Springer 2016. Chapter 7: 95-114.

Al-Meles, M. 2007. Understanding people's attitude towards the use and impact of 'Wasta'[Nepotism] in Kuwait. Suggesting practical ways of overcoming negative attitudes and demotivation in people through organisational behavioural change in key areas [recruitment \& selection], Cranfield School of Management, Working Paper.

Alsane, N. 1994. Developing management in the countries of the Gulf Co-operative Council. Paper presented to the Arab Management Conference 1994, Bradford: University of Bradford Management Centre.

Al-Suwaidi, M.A. 2008. When an Arab executive says "Yes": Identifying different collectivist values that influence the Arabian Decision-Making Process. MA thesis of University of Pennsylvania accessed at https://repository.upenn.edu/cgi/viewcontent.cgi?article=1018\&context=od_theses_msod on February 15, 2018.

Arnove, R. F., Torres, C. A. and Franz, S. 2012. Comparative Education: The Dialectic of the Global and the Local: Rowman \& Littlefield Publishers.

Anderson, J. C., Håkansson, H., \& Johanson, J. 1994. Dyadic business relationships within a business network context. Journal of Marketing, 58(4), 1-15.

Anderson, J. C., \& Narus, J. A. 1990. A model of distributor firm and manufacturer firm working partnerships. Journal of Marketing, 54(1), 42-58. 
Anderson, R. 2016. Wasta seen as main source of corruption in Saudi, Gulf Business, 21 June 2016, Accessed at http://gulfbusiness.com/wasta-seen-main-cause-corruption-saudi/ on August 3, 2018.

Asharq Al-Awsat. 2004. "Abdulla Al-Ahmar pardons his daughter's killer". Accessed at http://archive.aawsat.com/details.asp?article=269578\&issueno=9505\#.Vlk3WUeUeCo $\quad$ on March 11, 2018 (Arabic text).

Ayubi, N. 1986. Bureaucratization as Development: Administrative Development and Development Administration in the Arab World, International Review of Administrative Science, 52: 201-222.

Azra, A. 2016. Koneski, Kolusi, and Nepotism (KKN): Culturally Embedded? The Indonesian Esperience of Combating Negative Wasta. In: Ramady, M.A. (editor): The political economy of Wasta: use and abuse of social capital networking: Berlin: Springer 2016. Chapter 11: 161172.

Badawy, M.K. 1980. Styles of Mid-Eastern managers. California Management Review, 22(2), $51-8$

Bailey, D. C. 2013. Women and Wasta: The Use of Focus Groups for Understanding Social Capital and Middle Eastern Women. The Qualitative Report, 17(33): 1-18. Accessed at http://nsuworks.nova.edu/tqr/vol17/iss33/1 on March 11, 2018.

Barnes, J. A. 1969. Graph theory and social networks: A technical comment on connectedness and Connectivity. Sociology 3(2):25-32.

Barnes, J. A. 1972. Social Networks. Modular Publications in Anthropology. 26. Reading, Mass.: Addison-Wesley.

Barnett, A., Yandle, B., and Naufal, G. 2013. Regulation, trust, and cronyism in Middle Eastern societies: The simple economics of 'Wasta', The Journal of Socio-Economics, 44: 4146. 
Brandstaetter, T. Bamber, D. and Weir, D.T.H. 2016. Wasta: Triadic trust in Jordanian Business. In: Ramady, M.A. (ed.): The political economy of Wasta: use and abuse of social capital networking: Berlin: Springer 2016. Chapter 5: 65-78.

Brouthers, K.D. 2002. Institutional, cultural and transaction cost influences on entry mode choice and performance, Journal of International Business Studies, 33 (2): 203-221.

Burt, R. S. 2000. The network structure of social capital. Research in Organizational Behavior, 22, 345-423.

Chaston, I. and Mangles, T. 2000. Business networks: assisting knowledge management and competence acquisition within UK manufacturing firms. Journal of Small Business and Enterprise Development, 7(2): 160-170.

Chennoufi, B., and Weir, D.T.H. 2000. Management in Algeria. In: M. Warner (ed.), Management in Emerging Countries: Regional Encyclopaedia of Business and Management. London: Business Press/Thomson Learning: 176-181.

Coase, Ronald. 1983. The Nature of the Firm. Economica, 4: 386-405.

Cunningham, R B. and Sarayah, Y. 1993. Wasta: The Hidden Force in Middle Eastern Societies. New York: Praeger. Google Scholar

Cunningham, R.B., and Sarayrah, Y.K. 1994. Taming Wasta to Achieve Development, Arab Studies Quarterly, 16(3): 29-39.

Dadfar, H. 1993. In search of Arab management, direction and identity. Paper presented to the Arab Management Conference 1993, Bradford, University of Bradford Management Centre.

Doughan, Y. 2017. Corruption in the Middle East and the Limits of Conventional Approaches (GIGA Focus Nahost, 5). Hamburg: GIGA German Institute of Global and Area Studies Leibniz-Institut für Globale und Regionale Studien, Institut für Nahost-Studien. Accessed at http://nbn-resolving.de/urn:nbn:de:0168-ssoar-53438-8 August 5, 2018.

Dwyer, F.R., Schurr, P.H., and Oh, S. 1987. Developing buyer-seller relationships, Journal of Marketing, 3 (2): 7-23. 
El-Tayeb, H. 1986. Administrative Reform in the Arab Countries: Between the Original and Contemporary. In: Al-Saign, N. (ed.), Administrative Reform in the Arab Countries: Readings. Amman: Arab Organization of Administrative Sciences: 116-165.

Erkal, N. and Kali, R. 2011. Political Connections, Entrepreneurship, and Social Network Investment, University of Melbourne, Working Paper.

Feghali, R. 2014. Wasta: Connections or Corruption in the Arab World, Nardello\&Co, April. Accessed at https://www.nardelloandco.com/insights/wasta-connections-or-corruption-in-thearab-world/ August 3, 2018.

Ford, D., Gadde, L. E., Håkansson, H., \& Snehota, I. 2003. Managing business relationships (2nd ed.) Chichester: Wiley.

Ford, D., Gadde, L. -E., Håkansson, H., \& Snehota, I. 2006. The business marketing course: Managing in complex networks (2nd ed.), Chichester: Wiley.

Fuller, G.E. and Lesser, I.O. 1996. A Sense of Siege: The Geopolitics of Islam and the West, Arab Studies Quarterly. 18 (3): 87-91.

Garbett, K. 1970. The Analysis of Social Situations, MAN, 5 (2): 214-27.

Gold G.D., and Naufal, G.S. 2012. Wasta: The Other Invisible Hand: A Case Study of University Students in the Gulf, Journal of Arabian Studies: Arabia, the Gulf, and the Red Sea, 2 (1)1: 59-73.

Granovetter, M. 1973. The strength of weak ties. The American Journal of Sociology, 78(6), 1360-1380.

Granovetter, M. 1985. Economic action and social structure: The problem of embeddedness. The American Journal of Sociology, 91(3), 481-510.

Granovetter, M. 2005. The impact of social structure on economic outcomes. Journal of Economic Perspectives, 19(1), 33-50.

Hamdy, A.A.M.H., 2008. The Stigma of Wasta The Effect of Wasta on Perceived Competence and Morality, Faculty of Management Technology, January, German University of Cairo. 
Hampden-Turner, C. and Trompenaars, F. 2015. Nine Visions of Capitalism: unlocking the meanings of wealth-creation. Oxford, Infinite Ideas.

Hearn, G. and Pace, S. 2006. Value-creating ecologies: understanding next generation business systems, Foresight, 8(1): 55-65.

Hennart, J.F., and Larimo, J. 1998. The impact of culture on the strategy of multinational enterprises: Does national origin affect ownership decisions, Journal of International Business Studies, 29 (3): 515-538.

Hickson, D., and Pugh, D. 1995. The Arabs of the Middle East, in: Hickson, D., and Pugh, D. (eds.), Management Worldwide. Harmondsworth, Penguin.

Hilber, Christian A. L. and Lyytikäinen, Teemu. 2013. Housing Transfer Taxes and Household Mobility: Distortion on the Housing or Labour Market? (August 9). Government Institute for Economic Research VATT Working Papers 47/2013.

Hofstede, G. 1980. Culture's Consequences: Comparing Values, Behaviors, Institutions, and Organisations Across Nations. Thousand Oaks, Sage.

Hooker, J. Corruption from a Cross-Cultural Perspective, Carnegie-Mellon University, 2008. Working paper. Accessed at http://web.tepper.cmu.edu/jnh/corruption08s.pdf on March 11, 2018.

Hutchings, K. 2003. Cross-Cultural Preparation of Australian Expatriates in Organisations in China: The Need for Greater Attention to Training, Asia Pacific Journal of Management, 20 (3): $375-396$.

Hutchings, K., and Murray, G. 2002. Australian Expatriates' Experiences in working behind the Bamboo Curtain: An Examination of Guanxi in post-Communist China, Asian Business Management, 1: 1-21.

Hutchings $\mathrm{K}$ and Weir DTH. 2005. Cultural embeddedness and contextual constraints: knowledge sharing in Chinese and Arab cultures, Journal of Knowledge and Process Management, 12 (2): 89-98. 
International Organization for Migration. 2010. Intra-regional Labour Mobility in the Arab World, Facts and Figures. Accessed at https://publications.iom.int/books/intra-regionallabour-mobility-arab-world on August 5, 2018.

Kabasakal, H. and Dastmalchian, A. 2001. Introduction to the Special Issue on Leadership and Culture in the Middle East. Applied Psychology: An International Review. 50 (4) October: $479-488$.

Kabasakal, H. and Muzaffer. B. 2002. Arabic cluster: a bridge between East and West. Journal of World Business. 37 (1) Spring: 40-54.

Kacanski S. and Lusher, D. 2017. The Application of Social Network Analysis to Accounting and Auditing, International Journal of Academic Research in Accounting, Finance and Management Sciences, 7(3):82-97.

Kar, HM, Nazioglu, S. and Agir, H. 2011. Financial development and economic growth nexus in the MENA countries: Bootstrap panel granger causality analysis. Economic Modelling, 28 (1-2), January-March: 685-693.

Karalok, M. 2016. Quality-Oriented Education and Workforce Reform: The Impact of Wasta (Case Study of Bahrain). In: Ramady, M.A. (ed.): The political economy of Wasta: use and abuse of social capital networking: Berlin: Springer 2016. Chapter 10: 145-160.

Larsen A.G.and Ellersgard, C.H. 2018. Who listens to the top? Integration of the largest corporations across sectoral networks. Acta Sociologica. August 3.

Leuthesser, Lance and Kohli, Ajay K. 1995. Relational Behavior in Business Markets: Implications for Relationship Management. Journal of Business Research, 34(3): 221-233.

Loewe, M., Blume, J., Schonleber, V., Seibert, S., Speer, J., and Voss, C. 2007. The Impact of Favouritism on the Business Climate. A Study on Wasta in Jordan. Deutsches Institut fur Entwicklungspolitik, Bonn. Accessed at https://www.diegdi.de/uploads/media/Studies_30.pdf on August 4, 2018.

Li Y., Du J., and Van de Bunt S. 2015. Social capital networking in China and the traditional values of Guanxi. In: The political economy of "Wasta": use and abuse of social capital networking, Ramady, M. (ed.), Springer Publishers, Chapter 12: 173-183. 
Mann, L. 2014. Wasta! The long-term implications of education expansion and economic liberalisation on politics in Sudan. Review of African Political Economy, 41 (142): 561-578.

Mathew, V., and Kavitha, M. 2010. Women entrepreneurs practicing business in Middle East: case study of socio-cultural environmental barriers, International Journal of Arab Culture, Management and Sustainable Development, 1(3): 239 - 253.

Mitchell, C. 1969. Introduction, in: C. Mitchell (ed.), 1969. Social networks in urban situations: Analyses of personal relationships in central African towns. Manchester: Manchester University Press: 1-9.

Mitchell, J.C. 1974. Social Networks: Annual Review of Anthropology, 3: 279-299.

Mitchell, C. 1976. The concept and use of social networks, in: Evans, W.M. (ed.), Interorganizational Readings. New York: Penguin: 293-306.

Mitrega, M., Forkmann, S., Ramos, C., \& Henneberg, S. C. 2012. Networking capability in business relationships - Concept and scale development. Industrial Marketing Management, 41(5), 739-751.

Mort, G. S., \& Weerawardena, J. 2006. Networking capability and international entrepreneurship. International Marketing Review, 23(5), 549-572.

Mulnix, M.W., Beede, P. and López-Mulnix. 2014. Emerging issues among women Emirati entrepreneurs: a research agenda, European Scientific Journal, 1, June, accessed at http://eujournal.org/index.php/esj/article/view/3638 on March 11, 2018.

NATO. 2002. Press Conference by US Secretary of Defence, Donald Rumsfeld, 6 June, accessed at: https://www.nato.int/docu/speech/2002/s020606g.htm, on June 12, 2018.

Ouchi, W. 1980. Markets, bureaucracies and clans, Administrative Science Quarterly, 25: 12962.

Park, S.H., and Ungson, G.R. 1997. The Effect of National Culture, Organizational Complementarity, and Economic Motivation on Joint Venture Dissolution, Academy of Management Journal, 40 (2): 279-307. 
Pew. 2015. World's Muslim Population Will Surpass Christians This Century, Pew Says. The Two-way. Pew Research Centre. April 2. Accessed at https://www.npr.org/sections/thetwoway/2015/04/02/397042004/muslim-population-will-surpass-christians-this-century-pew-says on June 6, 2018.

Lipka, M. and Hacket, C. 2017. Why Muslims are the world's fastest-growing religious group. PEW Research, Accessed at http://www.pewresearch.org/fact-tank/2017/04/06/why-muslimsare-the-worlds-fastest-growing-religious-group/ on June 12, 2018.

Quran, Al-Qasas: chapter 28, verse 26, accessed at https://quran.com/28/26 on March 11, 2018.

Rice, G. 2004. Doing Business in Saudi Arabia, Thunderbird International Business Review, 46 (1): $59-84$.

Rice, G. 2003. The challenge of creativity and culture: a framework for analysis with application to Arabian Gulf firms. International Business Review. 12, 461-377.

Riege, A. 2005. Three dozen knowledge sharing barriers managers must consider. Journal of Knowledge Management, 9(3): 18-35.

Ritter, T. 1999. The networking company: Antecedents for coping with relationships and networks effectively. Industrial Marketing Management, 28(5), 467-479.

Sadi, W. 2017. Wasta, and wasta. In : The Jordan Times. July 29. Accessed at http://jordantimes.com/opinion/walid-m-sadi/wasta-and-wasta on August 42018.

Sapsford, R., Tsourapas, G., Abbot, P., and Teti, A. 2017. Corruption, Trust, Inclusion and Cohesion in North Africa and the Middle East. Applied Research in Quality of Life. 26 December. Accessed at https://link.springer.com/article/10.1007/s11482-017-9578-8 on August 3, 2018.

Sawalha, F. 2002. Study says 'Wasta' difficult to stamp out when advocates remain in power, Jordan Times. April 1. 
Schein, E. 2013. Humble Inquiry. The gentle art of asking instead of telling. Berrett-Koehler Publishers.

Scott, J. 1991a. Networks of Corporate Power: A Comparative Assessment, Annual Review of Sociology. 17: 181-203.

Scott, J. 1991b. Social Network Analysis: A Handbook. London: Sage.

Siddiqi,M. 2015. Economic Outlook 2015, The Middle East Online. Accessed at http://www.themiddleeastmagazine.com/wp-mideastmag-live/2015/01/economic-outlook-

2015. on March 11, 2018.

Stanton, M. 1999. An Appreciative Inquiry into the Role of Islamic Values in Organisational Decision Making and Practices. Unpublished Masters of Organizational Science Thesis, Malibu, California, Graziadio School of Business, Pepperdine University.

Sultan, N., Metcalfe. B., and Weir, D. 2011. Building the Foundation for a Post-Oil Era: The Case of the GCC Countries. In : Sultan, N., Weir, D., and Karake, Z. (eds.), The New Post-Oil Arab Gulf: Managing People and Wealth, London: Al-Saqi, 15-44.

Sultan, N. and Weir, D. 2010. Hadhramis: The Great Entrepreneurial Leaders of Arabia, The European Academy of Management, paper presented at EURAM conference, 19-22 May, Rome, Italy.

Sultan, N. 2013, A Culture of Ethics and Social Responsibility: How a Class of Yemeni Businessmen Made it Work for Everyone', in: From Critique to Action: The Practical Ethics of the Organisational World (New Insights), Sultan, N. and Weir, D (eds.), Newcastle: Cambridge Scholars: 295-314.

Thornton, S.C., Henneberg, S.C., Naude, P. 2013. Understanding types of organizational networking behaviors in the UK manufacturing sector Industrial Marketing Management, 42: 1154-1166.

Thrift, N. 1993. Globalisation, Regulation, Urbanisation: The Case of the Netherlands, Urban Studies, 31 (3): 365-380. 
Trompenaars, F. and Hampden-Turner, C. 1997. Riding the Waves of Culture. London: Nicholas Brealey Publishing.

Trompenaars, F. and Coebergh, P.H. 2014. 100+ Management Models. Oxford: Infinite Ideas Limited.

Uzzi, B. 1996. The sources and consequences of embeddedness for the economic performance of organizations: The network effect. American Sociological Review, 61(4), 674-698.

Weir, D.T.H. 1998. The fourth paradigm. In: Al- Shamali, A., and Denton, J. (eds.), Management in the Middle East. Kuwait: Gulf Management Centre: 60-76.

Weir, D.T.H. 2003a. Human Resource Development in the Middle East: A Fourth Paradigm. In: Lee, M. (ed.), HRD in a Complex World. London, Routledge: 69-82.

Weir, D.T.H. 2003b. Management Development and Leadership in the Middle East: An Alternative Paradigm. Paper presented to the Leadership in the Management Theory at Work Series Conference, June 2003, Lancaster: Lancaster University.

Weir, D.T. H. 2008. Islamic Perspectives on Management and Organization, International Journal of Islamic and Middle Eastern Finance and Management 1(1): 84-7.

Weir, D.T.H. 2010. Space as context and content. In : Marrewijk, A. van, and Yanow, D. (eds.), Organizational Spaces: Rematerializing the Workaday, World, Edward Elgar. Chapter 9: 115-136.

Weir, D., Sultan, N., and Metcalfe, B. 2011. The Arabian Gulf as Knowledge-based Economies: The Challenge. In: Sultan, N., Weir, D., and Karake, Z. (eds.), The New Post-Oil Arab Gulf: Managing People and Wealth, London: Al-Saqi: 73-96.

Weir D. 2012. Islam, Belief System and Organization. In: Case P., Höpfl H., Letiche H. (eds.) Belief and Organization. Palgrave Macmillan, London.

Weir, D., Sultan, N., and Van de Bunt, S. 2015. Wasta: A Scourge or a Useful Management and Business Practice? In: The political economy of "Wasta": use and abuse of social capital networking, Ramady, M. (editor), Springer Publishers, Chapter 2: 23-31. 
Williamson, O.E. 1979. Transaction-cost economics: the governance of contractual relations, Journal of Law and Economics, 22: 3-61.

Williamson, O.E. 1975. Markets and Hierarchies: Analysis and Antitrust Implications. New York: Free Press.

Zakaria, N., Stanton, J. and Sarkar Barney, S.T.M. 2003. "Designing and implementing culturally sensitive IT applications: The interaction of culture values and privacy issues in the Middle East" Information Technology \& People, 16(1): 49-75. 